\title{
Research on the Laws Related to the Issues of Residential Parking Spaces and Parking Garages
}

\author{
Pengfei Ji \\ Department of Foundation, Northeast Petroleum University at Qinhuangdao, Qinhuangdao, China \\ Email: guicaitang@163.com
}

Received 30 January 2015; accepted 11 April 2015; published 14 April 2015

Copyright (C 2015 by author and Scientific Research Publishing Inc. This work is licensed under the Creative Commons Attribution International License (CC BY). http://creativecommons.org/licenses/by/4.0/ c) (i) Open Access

\begin{abstract}
In recent years, the issue of the ownership of residential parking spaces has caused increasingly lots of disputes. "Real Right Law" has given some provisions to determine the ownership of residential parking spaces, but there also exist some problems. The author has proposed some specific solutions after analyzing relevant provisions of "Real Right Law" on the issue of residential parking spaces.
\end{abstract}

Keywords

Parking Space, Parking Garage, Partitioned Ownership of the Building, Legal Parking Space

\section{Introduction}

As people's living standards improved, there are more and more private cars, so residents need more parking spaces. Although garage is growing, its ownership has been a blind spot of the condominium ownership system. Enacting and implementation of "Real Right Law" is significant and positive to solve the right of ownership of residential garage and parking spaces, but the system still needs further improvement. The author combines his own opinions with the relevant provisions of the "Real Right Law" to do the research on the laws related to the issues of residential parking spaces and parking garages.

\section{Types of Parking Spaces and Parking Garages}

According to the land-use right types of the building land and the occupied space, the residential parking spaces and parking garages can be divided into three types at present: the first type is the ground parking space and parking garage. The ground parking space refers to an open parking facility with a "planning permit for building 
engineering” issued by the planning department of the government, directly arranged on the ground of commercial housing residential area, by means of marked segmentation without any structures, and used for many people at same time [1]. The independent ground parking garage refers to the special-purpose parking space in the residential district, built with walls and doors, and isolated from outside space. The second type is the firstlayer parking space and parking garage by making use of the first layer of the building set up with walls and columns, and affiliated to building. The third type is the underground parking space and parking garage by making use of the underground space of residential district. The interior is provided with a lot of lines and numbers with no isolating walls.

\section{The Issue on the Ownership of Parking Space and Parking Garage under Current Law}

The Article 74 of "Real Right Law" has given a series of special provisions for the issue of the ownership of the parking spaces and garages. The first paragraph of Article 74 provides "the parking spaces and garages within the building area planned for parking cars shall be used to meet the needs of the owners above all else”. The second paragraph provides: "the ownership of the parking places and garages shall be agreed upon by the related parties in the manners of selling, complementary using or leasing, etc.” Through these two provisions, we possibly could draw such a conclusion: according to Article 74, the legislator gives the ownership of parking spaces and parking garages for parking car within the building to the developers who can sell, give or lent them to a specific person respectively through sale contract, donation contract or lease contract. But this understanding seems only the literal interpretation of the provisions. In reality, the conflicts between the owners and developers on the legal issue of parking spaces and parking garages do not seem to be ceased. Then how to determine the ownership of parking spaces and parking garages?

First of all, the third paragraph of Article 74 of "Real Right Law" provides: "the parking places, which occupy the roads or other fields commonly owned by all owners, shall be in the common ownership of all the owners". The ground parking space mentioned above refers to the parking facility with a "planning permit for building engineering” from the government, set by the commercial housing developer directly in the residential district. The ground parking lot is not building; it is a parking place on the ground, so it is impossible to obtain the initial registration of real estate property right and the real estate certificate. In fact, the ground parking lot is not independent; it is a way to use land. The rights to use the land occupied by the parking lot shall belong to all the owners. Therefore, the ground parking lot shall be in the common ownership of all the owners.

Secondly, the key to determining the ownership of the ground parking garage is to see whether developers apportion the land area occupied by the parking garages to all owners. If the developer has apportioned the land to all owners, it means the parking garage shall be in the common ownership of all the owners. And the developer couldn't specify the ownership separately. This relates to the burden of proof. The developers and the owners on this issue have serious information asymmetry condition, it is very necessary to clear developers' burden of proof through legislation or legislative interpretation [2].

The most difficult problem is the ownership of the underground garage. We can analyze it from the following two aspects.

\subsection{The Relationship between the Land-Use Right and the Ownership of the House}

Article 31 of "Law on Management of Urban Real Estate” provides: "Where real estate is transferred or mortgaged, the ownership right of the premises on the land is transferred or mortgaged along with the land-use right." Through the above legal provision, it can be seen that our country carries out the single transfer mode: "land transferred accompanies the building transferred”. If the housing developers sell the housing ownership to the buyers, then the land-use right should also be transferred to buyers. If the ownership of house is separated with the land-use right, they will be enjoyed by different subjects. The owners of land and house are difficult to use the house and land. Most of residential garages are constructed inside the residential district, affiliated to the residential land or building. Since both the housing ownership and land ownership are transferred to the housing buyer, the residential garage affiliated to the residential land should belong to the housing buyers [3].

\subsection{The Partitioned Ownership of the Building}

According to the principle of partitioned ownership of the building, the object of the partitioned ownership of 
the building can be divided into the exclusive part and the common part. The common part of the partitioned ownership of the building can not be the object of sole ownership, while it should be owned by all partitioned owners of the building. As to the garage, if the garage belongs to the common part of partitioned ownership of the building, the garage should be owned by all the partitioned owners of the building. If the garage doesn't belong to the common part of partitioned ownership of the building, the garage can be used as the exclusive part. The ownership of the garage doesn't belong to all owners [4].

In the real world, the ownerships of the residential garage are not transferred to the housing buyers along with the transfer of exclusive parts. The housing buyers should sign lease contracts and pay rent to get the use right. However, it does not affect the legal attribute of its common part. Even if they sign lease contracts, the contracts are within the interior of residential owners. Only the members generated from common relationship have the rental qualification. If the residential garage is determined as common part, the interest of residential owners will be well protected and it also conforms to the concept of partitioned ownership of the building in modern times.

In reality, the residential property owner does not necessarily need the garage, so requiring all owners to share all expenses of the construction of the residential garage may go against the willingness of all owners. In one situation, the developer does not account the floor area ratio of the underground garage into the total area of the building (the floor area ratio is an architectural term for the ratio of a building's total floor area to the size of the piece of land upon which it is built), considering that the developer may suffer the profit losses from the additional investment in the construction of garage, it is unfair if the garage is owned by all residential owners. In another situation, it is difficult to figure out whether the investment in residential garage is calculated in the sale price of commercial housing, what's more, whether to account it into the housing price entirely depends on the developer, making it impossible for the owner to know about it. When there is a conflict, the developers tend to use their powerful position to present many evidences to support their ownership of the garage, while the owners are in a complete disadvantage. Since the "Real Right Law" does not specify this situation. If the developer is required to prove whether he is involved in the "secondary sales", he needs to provide the certification issued by price control authorities stating there is no cost-sharing and the garage is not included in the residential pool area, and then the property ownership of garage (parking space) can be determined independently. If the developer who has the responsibility to provide the evidence fails to provide the evidence by himself, he shall take the consequences as a result of the absence of evidence. The author believes that it is fair to allocate the responsibility for the presentation of evidence in this way, which helps protect the rights and interests of all parties, in addition, the People's Court can use the relevant material submitted by the responsible authorities based on the application by the party to solve the problem whether the garage should be accounted into the residential pool area and then to determine whether the "contract of secondary sale" is valid.

\section{The Existing Legal Defect and Its Solution}

First, the Paragraph 1 of Article 74 in the "Real Right Law" states that it is the first priority to meet the need of the owner, and this provision is over generalized and lack of practicality. The developer often offers a price higher than the market price to force the owner to waive his right of priority to buy or rent the parking space and garage, as a result, the developer uses that as a reason to sell or rent the parking space and garage to someone rather than the owner for use, which greatly damages the interests of the owner and there is nothing the owner can do to change it. In this regard, there should be legislative stipulations to forbid the developer from selling or renting the residential garage to any owner at a price significantly higher than the market price, and governmental construction administrations should supervise the developer, and the developer should examine the price of garage and other parts, specially publicize or inform in a simple and definite words the owner of which land is accounted into the residential pool area [5]. If the garage is built upon a certain plot which has been accounted into the residential pool area, the developer should appropriately lower the transfer or rental price.

Second, the Paragraph 2 of Article 74 in the "Real Right Law" allows the ownership of residential parking space and garage is determined depending on the agreement between the parties, but excludes the issues on the determination of ownership when the agreement is uncertain or there is no agreement, causing difficulty in the practical operation. In this case, it should be presumed to be owned by all owners based on the following reasons: first, the developer has a economically-dominant position and can fight for his own best benefit utilizing the model contract. The developer can prove the ownership of garage in virtue of his good knowledge of the costs of 
construction of commercial housing, and if the developer fails to point out the ownership of garage in the contract, it can be presumed that he has given up a claim to the garage; second, from the perspective of contract interpretation, the developer is the one who generally draws up a contract unilaterally and even determines the ownership of garage in standard terms in practice, if there is any conflict merely because no ownership agreed upon in the contract, it should be interpreted unfavorably to the developer according to the rules of interpretation of contract, what's more, the logic of this paragraph is vague. Under the Article 212 of the "Contract Law”, a lease contract refers to a contract whereby the less or shall deliver the leased property to the lessee for the latter's use or obtaining proceeds through the use, and the lessee pays the rent, and therefore a lease contract only transfers the right to use or to profit from the subject matter rather than the ownership of the subject matter. This provision allowing the ownership of parking space to be agreed upon in the way of leasing is obviously improper and thus should be corrected.

Furthermore, administrative authorities should specify whether the garage area is accounted into the total building area in the planning. The developer who invests and constructs the garage is bound to earn some profit utilizing cost accounting. As a result, when garage area is accounted into the building area, the developer can profit from the separate garage sales or garage area-sharing; when garage area is not accounted into the building area, the developer tends to add the garage cost to the total cost of the house, and then profits from the house sales (on the surface, the garage is not sold, but it is actually sold), so whether accounting garage area into the total building area makes no difference on the interests of developer. One advantage of accounting it into total area is to define the legal statue in which garage can be sold as well as the ownership of garage in a form of certificate of entitlement, reducing the ownership dispute and playing a role in settling a dispute. The disadvantage of excluding the garage area from the total area is that the ownership is undefined (in fact, it is clear and conferred to all owners), and unscrupulous businessmen may seek illegitimate benefits in this way.

In practice, I think we can refer to the practice in Taiwan, China whose law has introduced the legal parking space. The legal parking space is the parking space provided as required by the law and designed as legal space for parking and emergency. The legal parking space is nontransferable separately because it is the common property used for building possession differentiation in nature and a common part of the building as a subsidiary. If the legal parking space is applied, real estate developer has to define the ownership of such parking space (garage), and he is required to account the building area of such parking space (garage) into the residential pool area and add its expenses to the house sale price, and only the residential owner is allowed to use such parking space (garage) and real estate developer is prohibited from selling, renting or giving away such parking space (garage) for profit. If a real estate developer acts like this, the owner can claim the sale, rental or giving is invalid. The non-profitable legal parking space can fully guarantee the parking space has a reasonable market price and subjects to the market regulation rather than controlled completely by the developer. The developer must provide the parking space at a certain proportion in the process of constructing commercial housing to meet the need of owners in the future. Certainly, according to the principle of "the investor is the beneficiary", the developer is allowed to profit from other additional parking lots built by him as long as he has fulfilled the obligation to build the legal parking space, which not only ensures the demand of owner, but improves the motivation of the developer to build parking lots.

\section{Conclusions}

Facing the development trend of complex needs of owners and the increasing development of the technology of parking facilities, we should pay more attention to the balance of developers, owners and the interests of the third person for constructing and perfecting the "Real Right Law”, condominium ownership and use system.

It is necessary to point out that solving the parking problem in urban China, only by the property law is not enough, and practice actively supporting the implementation depends on the legal system and other administrative system as well as the majority of urban residents and property management agencies and participation.

\section{References}

[1] Jin, J. (2004) Study on the Real Estate Law. Science Press, Beijing, 161.

[2] Chen, Y.D. (2003) A Special Discussion on the Legal Issues of Sales of Commercial Property. Law Press, Beijing, 33.

[3] Cai, Y.B. (2011) A Brief Analysis on the Ownership of Residential Parking Space and Garage. Academic Exchanges, 7. 
[4] Han, J. and Liu, L. (2014) Discussion on the Legal Issues of the Ownership of Residential Parking Space and Garage. Legality Vision (Mid-Monthly), 11.

[5] Xu, B.G. and Tian, X.K. (2012) A Study of Issues on the Ownership of Residential Parking Space and Garage in China. Journal of Changchun University of Science and Technology, 12. 